\title{
Antinociceptive Anti-inflammatory Effect of Monotropein Isolated from the Root of Morinda officinalis
}

\author{
Jongwon ChOI, ${ }^{a}$ Kyung-Tae LeE, ${ }^{b}$ Moo-Young ChOI, ${ }^{c}$ Jung-Hwan NAm, ${ }^{d}$ Hyun-Ju JunG, ${ }^{d}$ \\ Sun-Kyu PARK, ${ }^{d}$ and Hee-Juhn PARK ${ }^{*}, d$ \\ ${ }^{a}$ College of Pharmacy, Daeyeon-Dong, Kyungsung University; Busan 608-736, Korea: ${ }^{b}$ College of Pharmacy, \\ Dongdaemun-ku, Hoegi-Dong, Kyung-Hee University; Seoul 130-701, Korea: ${ }^{c}$ Department of Food and Nutrition, Sangji \\ University; Woosan-Dong, Wonju 220-702, Korea: and ${ }^{d}$ Department of Botanical Resources, Sangji University; Woosan- \\ Dong, Wonju 220-702, Korea. Received May 2, 2005; accepted July 6, 2005
}

The root of Morinda officinalis (Rubiaceae) is used to treat rheumatoid arthritis and impotence in the traditional Oriental medicine. To identify the antinociceptive anti-inflammatory components of this crude drug, we adopted an activity-directed fractionation approach. The active fraction of the BuOH extract of $M$. officinalis root was subjected to silica gel and ODS column chromatography to yield two diterpenes, compounds 1 and 2 and these were identified as monotropein and deacetylasperulosidic acid, respectively. The iridoid glycoside, monotropein, was tested for its anti-inflammatory antinociceptive effects using hot plate- and writhing antinociceptive assays and by using carrageenan-induced anti-inflammatory assays in mice and rats. Pretreatment with monotropein (at $20,30 \mathrm{mg} / \mathrm{kg} / \mathrm{d}$, p.o.) significantly reduced stretching episodes and prolonged action time in mice. It also significantly reduced acute paw edema by carrageenan in rats. These results indicate that monotropein contributes to the antinociceptive and anti-inflammatory action of Morinda officinalis root.

Key words Morinda officinalis; Rubiaceae; iridoid glycoside; monotropein; antinociceptive; anti-inflammatory

Morinda citrifolia (Rubiaceae) is commonly known as noni is indigenous to the Hawaian and Tahitian islands. A number of constituents have already been isolated from this plant, and they include anthraquinones, flavonoids, iridoids and oligosaccharides. ${ }^{1)}$ Moreover, it has been established that the constituents of Hawaiian noni differ from those of noni found on the Indian sub-continent. Cimanga ${ }^{2)}$ reported on the isolation of iridoids with complement-inhibitory activity from Morinda spp. Moreover, the roots of Morinda officinalis (Rubiaceae) continue to be traditionally used to treat rheumatoid arthritis, diabetes and hypertension in North East Asia rather than $M$. citrifolia, which is also used in traditional medicine and said to have similar pharmacologic effect. Yang et al. ${ }^{3)}$ have reported on the anthraquinones from a $\mathrm{CHCl}_{3}$ extract of $M$. officinalis.

To isolate the active principle of $M$. officinalis, we used activity-directed fractionation. The main iridoid glycoside isolated, monotropein, was also examined by antinociceptive assay (hot plate test and writhing test) in mice and anti-inflammatory assay in rats with carrageenan-induced edema. Our investigation of the components of $M$. officinalis, resulted in the isolation of iridoid glycosides that were somewhat different from noni constituents. It is commonly known that many iridoid glycosides or other natural glycosides are easily hydrolyzed by intestinal bacteria. Therefore, we adopted oral administration approach for in vivo model to find the exact active compounds.

\section{MATERIALS AND METHODS}

Instruments Melting points were determined on an Electrothermal digital melting point apparatus; optical rotations on a JASCO DIP-360 digital polarimeter and IR spectra on a Bomem MB-100 FT-IR spectrometer. ${ }^{1} \mathrm{H}-\mathrm{NMR}$ spectra $\left(\delta \mathrm{ppm}, J\right.$ in $\mathrm{Hz}$ ) were recorded in $\mathrm{CD}_{3} \mathrm{OD}$ using a Bruker AM-500 spectrometer $(500 \mathrm{MHz})$, whereas ${ }^{13} \mathrm{C}-\mathrm{NMR}$ spectra were recorded in the same solvent using an AM-500 instru- ment at $125.5 \mathrm{MHz}$ with tetramethylsilane (TMS) as an internal standard. Sample purity was checked by TLC (Si gel, precoated plates, Merck, $\mathrm{PF}_{254}, 20 \times 20 \mathrm{~cm}, 0.25 \mathrm{~mm}$ ).

Plant Material The dried roots of Morinda officinalis (Rubiaceae) were purchased from the Chun-Il Herb Store in Wonju, Gangwon province, Korea, and the plant was identified by Prof. S. Y. Yun, Department of Botanical Resources, Sangji University, Korea.

Extraction, Fractionation and Isolation Dried powdered roots $(2.5 \mathrm{~kg})$ were extracted with $\mathrm{MeOH}$ (2.51) three times under reflux. The extract was then filtered and evaporated on a rotatory evaporator under reduced pressure. The concentrated extract was freeze-dried to give a solid $\mathrm{MeOH}$ extract $(185 \mathrm{~g})$. This $\mathrm{MeOH}$ extract was then suspended in $\mathrm{H}_{2} \mathrm{O}$, and partitioned with $\mathrm{CHCl}_{3}$. The $\mathrm{CHCl}_{3}$ layer was then concentrated in vacuo, and the extract so obtained was freeze-dried to give the $\mathrm{CHCl}_{3}$ extract $(28 \mathrm{~g})$. The residual $\mathrm{H}_{2} \mathrm{O}$ layer was successively fractionated with EtOAc $(8 \mathrm{~g})$ and $\mathrm{BuOH}(89 \mathrm{~g})$, in order, to give an EtOAc extract and a $\mathrm{BuOH}$ extract.

The $\mathrm{BuOH}$ extract $(40 \mathrm{~g})$ was found to contain an active fraction by activity-directed fractionation, and thus was chromatographed on a silica gel column $(600 \mathrm{~g}, 8.0 \times 30.0 \mathrm{~cm}$, Merck, Art 7734, Germany) using $\mathrm{CHCl}_{3}-\mathrm{MeOH}-\mathrm{H}_{2} \mathrm{O}$ (65:35:10, lower phase) as eluent to yield six fractions (Fr. 1-Fr. 6). On TLC documentation system (spectrophotometer CV-415.LS), it was shown that monotropein was contained in $\mathrm{BuOH}$ extract more than $85 \%$. Based on the results of preliminary anti-inflammatory testing, Fr. 3 was selected for further isolation. Accordingly, Fr. 3 was chromatographed on a ODS column (octadecylsilane $30 \mathrm{~g}, 3.0 \times 12.0 \mathrm{~cm}$, YMC, AA12S75, Japan) using $\mathrm{MeOH}-\mathrm{H}_{2} \mathrm{O}(10: 2)$ to afford compounds $\mathbf{1}$ and $\mathbf{2}$. These compounds were identified as monotropein and deacetylasperulosidic acid, respectively by spectral data.

Compound 1: Amorphous powder, mp $161-163^{\circ} \mathrm{C},[\alpha]_{\mathrm{D}}^{23}$ $-130.7^{\circ}\left(c=0.05, \mathrm{H}_{2} \mathrm{O}\right),{ }^{1} \mathrm{H}-\mathrm{NMR}\left(500 \mathrm{MHz}, \mathrm{CD}_{3} \mathrm{OD}\right) \delta$ : 
aglycone-2.68 $(1 \mathrm{H}, \mathrm{dd}, J=3.0,8.6 \mathrm{~Hz}, \mathrm{H}-8), 3.56(1 \mathrm{H}, \mathrm{m}, \mathrm{H}-$ 5), $4.67\left(1 \mathrm{H}, \mathrm{d}, J=7.9 \mathrm{~Hz}, \mathrm{H}-1^{\prime}\right), 5.55(1 \mathrm{H}, \mathrm{d}, J=7.9 \mathrm{~Hz}, \mathrm{H}-$ 1), $5.61(1 \mathrm{H}, \mathrm{dd}, J=1.9,5.6 \mathrm{~Hz}, \mathrm{H}-7), 7.35(1 \mathrm{H}, \mathrm{s}, \mathrm{H}-3), 6.21$ $(1 \mathrm{H}, \mathrm{dd}, J=2.5,5.6 \mathrm{~Hz}, J=6 \mathrm{~Hz}, \mathrm{H}-6) ;{ }^{13} \mathrm{C}-\mathrm{NMR}\left(\mathrm{CD}_{3} \mathrm{OD}\right.$, $125.5 \mathrm{MHz}) \delta$ : aglycone-40.1 (C-5), 46.2 (C-9), 68.9 (C-10), 86.8 (C-8), 95.7 (C-1), 112.8 (C-4), 133.9 (C-7), 138.8 (C-6), 152.3 (C-3), 172.2 (C-11), glucose-100.6 (C-1), 73.7 (C-2), 78.8 (C-3), 71.9 (C-4), 78.4 (C-5), 62.2 (C-6).

Compound 2: Amorphous powder, $[\alpha]_{\mathrm{D}}^{20}+26^{\circ}(c=1.7$, $\mathrm{MeOH}),{ }^{1} \mathrm{H}-\mathrm{NMR}\left(500 \mathrm{MHz}, \mathrm{CD}_{3} \mathrm{OD}\right) \delta: 2.55$ (1H, m, H-9), $3.00(1 \mathrm{H}, \mathrm{m}, \mathrm{H}-5), 3.61\left(1 \mathrm{H}, \mathrm{dd}, J=6.0,12.0 \mathrm{~Hz}, \mathrm{H}_{\mathrm{a}}-6^{\prime}\right), 3.85$ $\left(1 \mathrm{H}, \mathrm{d}, J=12.0 \mathrm{~Hz}, \mathrm{H}_{\mathrm{b}}-6^{\prime}\right), 4.21\left(1 \mathrm{H}, \mathrm{d}, J=15.5 \mathrm{~Hz}, \mathrm{H}_{\mathrm{b}}-10\right)$, $4.45\left(1 \mathrm{H}, \mathrm{d}, J=15.5 \mathrm{~Hz}, \mathrm{H}_{\mathrm{b}}-10\right), 4.72(1 \mathrm{H}, \mathrm{d}, J=8.0 \mathrm{~Hz}$, $\left.\mathrm{H}-1^{\prime}\right), 4.81(1 \mathrm{H}, \mathrm{dd}, J=1.8,5.9 \mathrm{~Hz}, \mathrm{H}-6), 5.05(1 \mathrm{H}, \mathrm{d}$, $J=8.9 \mathrm{~Hz}, \mathrm{H}-1), 6.01(1 \mathrm{H}, \mathrm{d}, J=1.8 \mathrm{~Hz}, \mathrm{H}-7), 7.65(1 \mathrm{H}, \mathrm{s}, \mathrm{H}-$ $3) ;{ }^{13} \mathrm{C}-\mathrm{NMR}\left(\mathrm{CD}_{3} \mathrm{OD}, 125.5 \mathrm{MHz}\right) \delta$ : aglycone-45.8 (C-1), 62.2 (C-10), 75.4 (C-5), 108.5 (C-4), 129.9 (C-7), 151.5 (C8), 155.4 (C-3), 170.9 (C-11); glucose-101.4 (C-1), 75.0 (C2), 78.5 (C-3), 71.6 (4), 77.8 (C-5), 61.7 (C-6).

Animals and Sample Preparation ICR male mice weighing $20-25 \mathrm{~g}$ and Sprague-Dawley male rats weighing $100-120 \mathrm{~g}$ were purchased from the Korean Experimental Animal Co. and maintained under constant conditions (temperature: $20 \pm 2{ }^{\circ} \mathrm{C}$, relative humidity: $40-60 \%$, light/dark cycle: $12 \mathrm{~h}$ ) for at least two weeks. Twenty-four hours before the experiment, animals were given only water. Due to diurnal enzyme activity, animals were sacrificed at a fixed time (10:00 am-12:00 am). The animal experiment was all performed without anesthesia.

The test samples (i.e., $\mathrm{MeOH}$ extract, $\mathrm{CHCl}_{3}$ extract, EtOAc extract, $\mathrm{BuOH}$ extract, and compound 1) were first dissolved in $10 \%$ Tween 80 and diluted with $0.9 \%$ saline before being orally administered. The same volume of solvent was administered to control rats and mice. Extracts were administered at 100 and $200 \mathrm{mg} / \mathrm{kg}$ once a day for a week and compound 1 was also orally administered at 20 and $30 \mathrm{mg} / \mathrm{kg}$ for the same period. Animal experiments were performed $30 \mathrm{~min}$ after the final administration; Aspirin $(100 \mathrm{mg} / \mathrm{kg}$, p.o.) and morphine $(10 \mathrm{mg} / \mathrm{kg}$, p.o. $)$ were used for positive controls.

Acetic Acid (Chemical-Induced) Writhing Assay Thirty minutes after orally administering test solutions (100 or $200 \mathrm{mg} / \mathrm{kg}$ ) or compound 1 (20 or $30 \mathrm{mg} / \mathrm{kg}$ ) were orally administered, $0.1 \mathrm{ml} / 10 \mathrm{~g}$ of $0.7 \%$ acetic acid was injected to the mice (10 mice/experimental group). ${ }^{4)}$ The numbers of abdominal contractions over the period of $20 \mathrm{~min}$ were counted. Acetylsalicylic acid $(100 \mathrm{mg} / \mathrm{kg}$, p.o. $)$ was used as a positive control. A significant reduction in the number of abdominal contractions compared to the control was considered as a positive analgesic response.

Hot Plates (Thermal) Testing Mice (10 mice/experimental group) were administered different doses of test solutions (100 or $200 \mathrm{mg} / \mathrm{kg}$ daily) or compound 1 (20 or $30 \mathrm{mg} / \mathrm{kg}$ daily) for 1 week at $1 \mathrm{~h}$ after final administration they were placed on a plate (Ugo Basile, Italy) maintained at $55 \pm 1.0^{\circ} \mathrm{C}$. The times taken by the animals to lick a fore or hind paw or to jump off the plate were defined as the reaction time. Morphine $(10 \mathrm{mg} / \mathrm{kg}$, p.o. $)$ was used as a reference drug.

Anti-inflammatory Activity Acute inflammation was produced by injecting $0.1 \mathrm{ml}$ of $1 \%$ carrageenan solution into the plantar surface of a single rat hind paw (10 mice/experimental group). Test solutions $(100,200 \mathrm{mg} / \mathrm{kg})$ and compound $1(20,30 \mathrm{mg} / \mathrm{kg})$, ibuprofen $(100 \mathrm{mg} / \mathrm{kg}$ orally) as a reference agent were administered for a week before carrageenan injection. Paw volumes were monitored for $0-5 \mathrm{~h}$ using a plethysmometer. ${ }^{5}$

Acute Toxicity Male ICR mice $(n=30)$ were fasted $18 \mathrm{~h}$ prior to the toxicity test and then treated with different doses of monotropein $(250,500,1000,2000 \mathrm{mg} / \mathrm{kg}$, p.o. $)$. The animals were kept for a period of $48 \mathrm{~h}$ under observation. $\mathrm{LD}_{50}$ by oral administration rout of compound $\mathbf{1}$ was measured at $937.5 \pm 773.9 \mathrm{mg} / \mathrm{kg}$.

\section{RESULTS AND DISCUSSION}

The $\mathrm{MeOH}$ extract of $M$. officinalis root was fractionated into $\mathrm{CHCl}_{3}-$, EtOAc- and $\mathrm{BuOH}$ extracts in an effort to isolate the component with antinociceptive/anti-inflammatory activity. The pretreatment of mice and rats with $\mathrm{BuOH}$ extract $(100,200 \mathrm{mg} / \mathrm{kg}$, p.o. daily for $7 \mathrm{~d})$ more significantly inhibited nociceptive or inflammatory response than the $\mathrm{CHCl}_{3}$ and EtOAc extracts by writhing- and hot plate testing in mice and carrageenan-induced edema testing in rats (Tables 1,2).

As shown in Table 1, the oral administration of 100 ,

Table 1. Antinociceptive Effect of the Methanolic Extract of M. officinalis Roots and of Its Fractionated Extract According to the Acetic Acid-Induced Writhing and the Hot-Plate Assay in Mice

\begin{tabular}{|c|c|c|c|c|c|}
\hline Treatment & $\begin{array}{c}\text { Dose } \\
(\mathrm{mg} / \mathrm{kg}, \text { p.o. })\end{array}$ & $\begin{array}{l}\text { Stretching episodes } \\
\quad(\text { count } / 20 \mathrm{~min})\end{array}$ & $\begin{array}{c}\text { Inhibition } \\
(\%)\end{array}$ & $\begin{array}{l}\text { Action time } e^{b)} \\
\text { (s) }\end{array}$ & $\begin{array}{c}\text { Increase } \\
(\%)\end{array}$ \\
\hline Control & - & $60.6 \pm 2.07^{\mathrm{a}}$ & - & $9.13 \pm 1.27^{f}$ & - \\
\hline \multirow[t]{2}{*}{$\mathrm{MeOH}$ extract } & 100 & $46.8 \pm 2.28^{\mathrm{d}}$ & $19.5^{\mathrm{a}}$ & $14.5 \pm 1.23^{\mathrm{cd}}$ & $58.8^{\mathrm{a}}$ \\
\hline & 200 & $37.8 \pm 1.30^{\mathrm{f}}$ & 37.6 & $15.6 \pm 1.27^{\mathrm{bcd}}$ & 70.9 \\
\hline \multirow[t]{2}{*}{$\mathrm{CHCl}_{3}$ extract } & 100 & $55.8 \pm 2.39^{b}$ & 7.9 & $10.4 \pm 1.14^{\mathrm{ef}}$ & 13.9 \\
\hline & 200 & $54.0 \pm 1.87^{\mathrm{b}, \mathrm{c}}$ & 10.9 & $11.6 \pm 1.33^{\mathrm{ef}}$ & 27.1 \\
\hline \multirow[t]{2}{*}{ EtOAc extract } & 100 & $55.0 \pm 3.53^{\mathrm{b}, \mathrm{c}}$ & 9.2 & $11.7 \pm 1.39^{\mathrm{ef}}$ & 28.1 \\
\hline & 200 & $52.6 \pm 3.05^{\mathrm{c}}$ & 13.2 & $13.2 \pm 2.10^{\mathrm{de}}$ & 44.6 \\
\hline \multirow{2}{*}{$\mathrm{BuOH}$ extract } & 100 & $43.2 \pm 1.48^{\mathrm{e}}$ & 36.6 & $14.9 \pm 1.42^{\mathrm{cd}}$ & 63.2 \\
\hline & 200 & $34.2 \pm 2.77^{\mathrm{g}}$ & 47.5 & $16.3 \pm 2.11^{\mathrm{bc}}$ & 78.5 \\
\hline Aspirin & 100 & $18.0 \pm 1.79^{\mathrm{h}}$ & 70.3 & NT & - \\
\hline Morphine & 10 & NT & - & $21.4 \pm 2.00^{\mathrm{a}}$ & 134.4 \\
\hline
\end{tabular}

${ }^{a}$ Values are $\%$ antinociceptive effect versus the control group. $\left.a, b\right)$ Methods indicate writhing-, and hot plate tests, respectively. NT (not tested). Values represent means \pm S.D. $(n=10)$. Values sharing the same superscript are not significantly different $(p<0.05)$ by Duncan's multiple range test. 
Table 2. Inhibitory Effect of the MeOH Extract of M. officinalis Roots and of Its Fractionated Extracts on Carrageenan-Induced Edema in Rats Hind Paw Model

\begin{tabular}{|c|c|c|c|c|c|c|}
\hline \multirow{2}{*}{ Treatment } & \multirow{2}{*}{$\begin{array}{c}\text { Dose } \\
(\mathrm{mg} / \mathrm{kg})\end{array}$} & \multicolumn{5}{|c|}{ Swelling volume (ml) } \\
\hline & & 1 & 2 & 3 & 4 & $5(\mathrm{~h})$ \\
\hline Control & - & $1.33 \pm 0.08^{\mathrm{a}}$ & $2.39 \pm 0.06^{\mathrm{a}}$ & $2.90 \pm 0.05^{\mathrm{a}}$ & $2.38 \pm 0.03^{\mathrm{a}}$ & $1.90 \pm 0.05^{\mathrm{a}}$ \\
\hline \multirow[t]{2}{*}{ MeOH ext. } & 100 & $1.29 \pm 0.05^{\mathrm{a}}$ & $1.97 \pm 0.07^{\mathrm{de}}$ & $2.21 \pm 0.06^{\mathrm{d}}$ & $1.77 \pm 0.02^{\mathrm{c}}$ & $1.87 \pm 0.07^{\mathrm{ab}}$ \\
\hline & 200 & $1.27 \pm 0.09^{\mathrm{a}}$ & $1.53 \pm 0.03^{\mathrm{f}}$ & $1.93 \pm 0.04^{\mathrm{f}}$ & $1.84 \pm 0.06^{\mathrm{de}}$ & $1.58 \pm 0.08^{\mathrm{de}}$ \\
\hline \multirow[t]{2}{*}{$\mathrm{CHCl}_{3}$ ext. } & 100 & $1.30 \pm 0.05^{\mathrm{a}}$ & $2.28 \pm 0.05^{\mathrm{b}}$ & $2.86 \pm 0.07^{\mathrm{a}, \mathrm{b}}$ & $2.26 \pm 0.05^{\mathrm{b}}$ & $1.85 \pm 0.06^{\mathrm{ab}}$ \\
\hline & 200 & $1.31 \pm 0.07^{\mathrm{a}}$ & $2.16 \pm 0.09^{c}$ & $2.77 \pm 0.09^{\mathrm{b}}$ & $2.27 \pm 0.08^{\mathrm{b}}$ & $1.89 \pm 0.05^{\mathrm{ab}}$ \\
\hline \multirow[t]{2}{*}{ EtOAc ext. } & 100 & $1.28 \pm 0.09^{\mathrm{a}}$ & $2.18 \pm 0.08^{b c}$ & $2.79 \pm 0.05^{\mathrm{b}}$ & $2.20 \pm 0.07^{\mathrm{b}}$ & $1.84 \pm 0.06^{\mathrm{ab}}$ \\
\hline & 200 & $1.31 \pm 0.08^{\mathrm{a}}$ & $2.03 \pm 0.07^{\mathrm{d}}$ & $2.60 \pm 0.08^{\mathrm{c}}$ & $2.18 \pm 0.04^{\mathrm{b}}$ & $1.79 \pm 0.03^{b c}$ \\
\hline \multirow[t]{2}{*}{ BuOH ext. } & 100 & $1.25 \pm 0.04^{\mathrm{a}}$ & $1.95 \pm 0.04^{\mathrm{de}}$ & $2.17 \pm 0.03^{\mathrm{d}}$ & $1.73 \pm 0.04^{\mathrm{cd}}$ & $1.73 \pm 0.05^{\mathrm{c}}$ \\
\hline & 200 & $1.26 \pm 0.03^{\mathrm{a}}$ & $1.48 \pm 0.06^{\mathrm{f}}$ & $1.86 \pm 0.05^{\mathrm{f}}$ & $1.59 \pm 0.03^{\mathrm{ef}}$ & $1.62 \pm 0.09^{\mathrm{d}}$ \\
\hline Ibuprofen & 100 & $0.79 \pm 0.04^{\mathrm{b}}$ & $1.17 \pm 0.06^{\mathrm{g}}$ & $1.41 \pm 0.06^{\mathrm{h}}$ & $1.22 \pm 0.09^{\mathrm{g}}$ & $0.93 \pm 0.05^{\mathrm{f}}$ \\
\hline
\end{tabular}

Values represent means \pm S.D. $(n=10)$. Values sharing the same superscript letter are not significantly different $(p<0.05)$ by Duncan's multiple range test.

$200 \mathrm{mg} / \mathrm{kg}$ of the $\mathrm{BuOH}$ extract reduced the number of writhings and stretchings induced by a $0.7 \%$ acetic acid i.p. injection by $28.7 \%$ and $43.6 \%$, respectively, and increased hot plate latency response by $63.2 \%$ and $78.5 \%$, respectively. Table 2 shows the inhibitory effect of $\mathrm{MeOH}$ extract and of its fractionated extract on carrageenan-induced edema; the $\mathrm{MeOH}$ extract had a significant effect at 100 and $200 \mathrm{mg} / \mathrm{kg}$. Of the fractionated extracts, the $\mathrm{BuOH}$ extract exhibited most effect, thus indicating that this fraction contains active components. It was also observed that the $\mathrm{CHCl}_{3}$ extract, which has been reported to contain anthraquinones, ${ }^{3)}$ was almost inactive.

We passed the $\mathrm{BuOH}$ extract through a silica gel column and then further purified the active fraction by ODS column chromatography to yield compounds $\mathbf{1}$ and $\mathbf{2}$, which were identified as monotropein (1) and deacetylasperulosidic acid (2) based on its physicochemical and spectroscopic data. ${ }^{6,7)} \mathrm{It}$ was shown on TLC that $\mathrm{BuOH}$ fraction contained much higher amount of the two compounds $(\mathbf{1}, \mathbf{2})$ than other two fractions. The structure of these two compounds is shown in Fig. 1. The NMR assignments are based on the known iridoid glycosides of asperulosidic acid, asperuloside and geniposidic acid from other plant sources, the ${ }^{13} \mathrm{C}$-NMR assignment of $\mathbf{2}$ has not been reported, and thus is reported here for the first time, as shown in Experimental section, after comparisons of the NMR data of those iridoid glycosides reported. ${ }^{8)}$ The present study is also the first to report the isolation of iridoid glycosides from $M$. officinalis. The more abundant compound 1 was examined for its antinociceptive/antiinflammatory activity using in vivo assay system. Interestingly, compounds $\mathbf{1}$ and $\mathbf{2}$ were found to have the same molecular formula, and it is known that the former monotropein is chemically unstable. ${ }^{9)}$ Therefore, it is possible that deacetylasperulosidic acid is produced through nucleophilic attack by $\mathrm{H}_{2} \mathrm{O}$ at olefinic C- 6 of monotropein and the successive elimination of $\mathrm{C}_{9}-\mathrm{OH}$. Compound $\mathbf{1}$ was successfully purified by sequential silica gel and ODS column chromatography.

Monotropein administration significantly reduced the number of writhings and stretchings caused by $0.7 \%$ acetic acid (Fig. 2). The percentage reductions in the writhing response afforded by monotropein were $36.6 \%$ and $47.5 \%$, respectively, at $100 \mathrm{mg} / \mathrm{kg}$ and $200 \mathrm{mg} / \mathrm{kg}$ and latencies by hot plate testing were prolonged by $64.3 \%$ and $96.1 \%$, respectively. These results suggest that monotropein possesses cen-

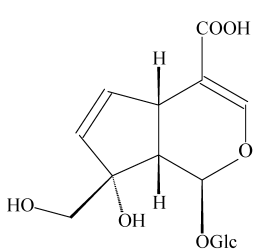

1

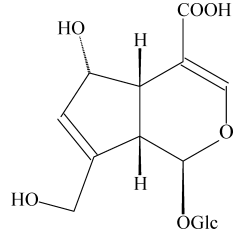

2
Fig. 1. Structure of Monotropein (1) and Deacetylasperulosidic Acid (2) Isolated from M. officinalis
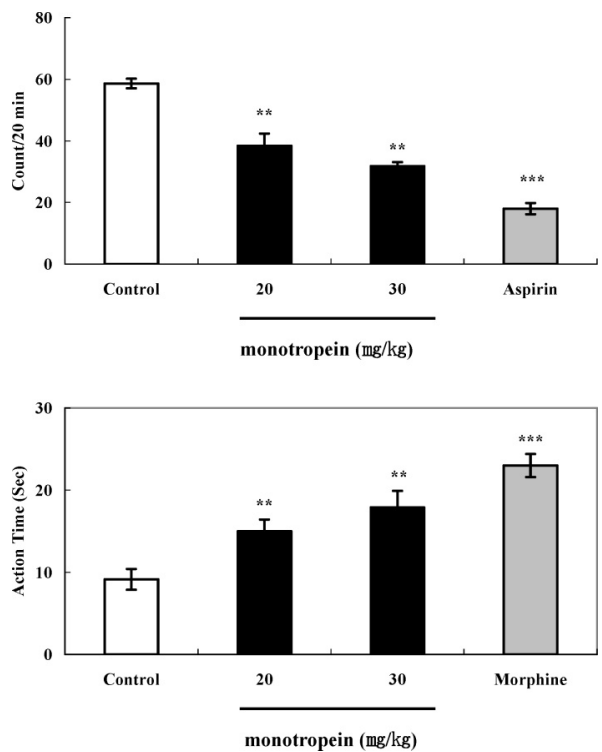

Fig. 2. Antinociceptive Effect of Monotropein Isolated from the Roots of M. officinalis by Acetic Acid-Induced Writhing and Hot-Plate Assays in Mice

Methods indicate writhing- (upper), and hot plate tests (down), respectively. Values represent means \pm S.D. $(n=10)$. $* *, * * *$ indicate significantly different means $(p<0.01$ and $p<0.001$, respectively) versus the normal untreated control.

trally and peripherally mediated antinociceptive properties.

As shown in Fig. 3, monotropein was found to have an anti-inflammatory effect $1 \mathrm{~h}$ after the carrageenan injection, and maximal edema inhibition was observed at $3 \mathrm{~h}$ after edema induction. In particular, treatment with monotropein $(30 \mathrm{mg} / \mathrm{kg}$, p.o. ) reduced the edema by $39.6 \%$ at $3 \mathrm{~h}$, and ibuprofen $(100 \mathrm{mg} / \mathrm{kg}$, p.o. $)$ treatment reduced edema rate by $62 \%$ on a volume basis. Moreover, this effect was significant 


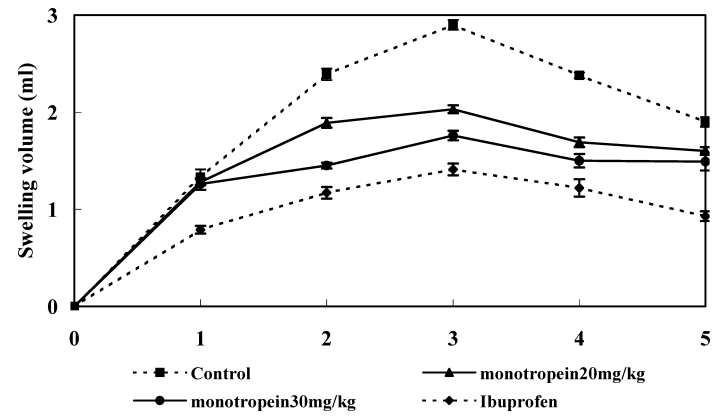

Fig. 3. Effects of Monotropein Isolated from the Roots of M. officinalis on Carrageenan-Induced Paw Edema in Rats

Values represent means \pm S.D. $(n=10)$.

for least $5 \mathrm{~h}$ after edema induction. When subjected to acute toxicity test using mice, any lethality was not observed up to $2000 \mathrm{mg} / \mathrm{kg}$ dose (p.o.). This result indicates that monotropein is very safe for clinical use.

Although a small number of reports have been issued on the biological activity of $M$. citrifolia, i.e. its inhibition of angiogenesis $^{10)}$ and LDL oxidation, ${ }^{11)}$ and on its nitric oxide scavenging activity, ${ }^{12)}$ few reports on the biological activity of $M$. officinalis have been reported. Soon ${ }^{13)}$ reported that $M$. officinalis extract has hypoglycemic and anti-oxidant activities, but did not isolate active compounds. In conclusion, the present report demonstrates for the first time that monotropein a component of the root of $M$. officinalis has an- tinociceptive/anti-inflammatory activities.

Acknowledgements This research was supported by a grant (PF0320301-00) from the Plant Diversity Research Center of the 21st Century Frontier Research Program funded by the Ministry of Science and Technology of the Korean government.

\section{REFERENCES}

1) Ho C. T., Zheng Q. Y., "Quality Management of Nutraceuticals," America Chemical Society, Washington DC, 2002, pp. 134-150.

2) Cimanga K., Hermans N., Apers S., Miert S. A., Heuvel H. V., Claeys L. P., J. Nat. Prod., 66, 97-102 (2002).

3) Yang Y. J., Shu H. Y., Min Z. D., Yao Xue Xue Bao, 27, 358-364 (1992).

4) Whittle B. A., Br. J. Pharmacol., 22, 246-260 (1949).

5) Winter C. A., Risley E. A., Nuss G. W., Proc. Soc. Exp. Biol. Med., 111, 544-548 (1962).

6) Boros C. A., Stermitz F. R., J. Nat. Prod., 53, 1055-1147 (1990).

7) Harborne J. B., "Dictionary of Natural Products," Vol. 9, Chapman \& Hall, New York, 1994, pp. 5054-5055.

8) Lee J. H., Ku C. H., Baek N. I., Kim S. H., Park H. W., Kim D. K., Arch. Pharm. Res., 27, 40-43 (2004).

9) Lee S. Y., Lee K. R., Lee S. H., Lee I. R., "Chemistry of Organic Natural Products," Younglimsa, Seoul, 1995, pp. 99-100.

10) Hornick C. A., Myers A., Sadowska-Krowicka H., Anthony C. T., Woltering E. A., Angiogenesis, 6, 143-149 (2003).

11) Kamiya K., Tanaka Y., Endang H., Umar M., Satake T. J., Agric. Food Chem., 52, 5843-5848 (2004).

12) Jagetia G. C., Baglia M. S., J. Med. Food, 7, 343-348 (2004).

13) Soon Y. Y., Tan B. K., Singapore Med. J., 43, 77-85 (2002). 